\title{
Left ventricular non-compaction
}

\author{
Christina Maria Steger
}

Department of Pathology, Academic Teaching Hospital Feldkirch, Affiliation of the Medical University Innsbruck, Feldkirch, Austria

\section{Correspondence to}

Dr Christina Maria Steger, Christina.Steger@lkhf.at

Accepted 6 June 2014

\section{CrossMark}

To cite: Steger CM. BMJ Case Rep Published online: [please include Day Month Year] doi:10.1136/bcr-2013203430

\section{DESCRIPTION}

In April 2011, a 13-month-old girl presented with dyspnoea, tachycardia and weight loss. Echocardiographic examination revealed a left ventricular non-compaction (LVNC), or spongy myocardium characterised by spongiform appearance of the left ventricle with deep recesses, a dilated left ventricle, a decreased left ventricular contractility, a grade 4 mitral valve regurgitation with dehiscence of the mitral valve leaflets and a grade 1 tricuspid valve insufficiency. There was no family history of LVNC; a gene mutation was not verified. Owing to the rapid progression of the heart failure and recurrent cardiac decompensation despite optimal medical treatment, the patient was listed high urgency for orthotopic heart transplantation, which was successfully performed in August 2011. Gross examination of the explanted heart showed a severe left ventricular dilation and endocardial fibrosis of the left ventricle with deep intertrabecular recesses (figures 1 and 2).

The patient is currently in good general condition and shows normal stages of development.

LVNC, first described by Engberding and Bender ${ }^{1}$ in 1984, is a rare congenital cardiomyopathy that is thought to result from an arrest in normal endomyocardial embryogenesis during cardiac partition at 5-8 weeks of fetal life. ${ }^{2}$

LVNC is characterised by an excessive number of deep trabeculations in the ventricular wall and intertrabecular recesses communicating with the left ventricular cavity. Although the disease is typically diagnosed in paediatric patients, the onset of symptoms can be delayed into adulthood. LVNC can be inherited as an autosomal or X-linked recessive disorder. Several gene mutations have been recently reported including LIM domain binding protein 3, $\alpha$-dystrobrevin, tafazzin, lamin $\mathrm{A} / \mathrm{C}$, $\beta$-myosin heavy chain, $\alpha$-cardiac actin, cardiac troponin $\mathrm{T}$, troponin I, cardiac myosin binding protein $\mathrm{C}, \mathrm{SCN} 5 \mathrm{~A}$ and tropomyosin 1.

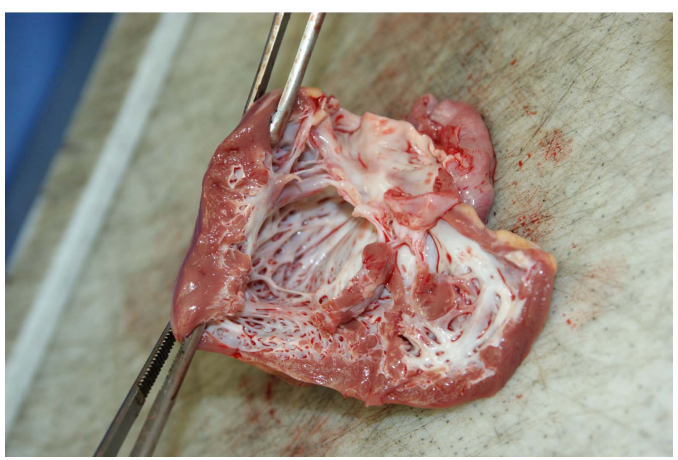

Figure 1 Explanted heart with left ventricular dilation and deep recesses, endocardial fibrosis and thickened leaflets of the mitral valve.

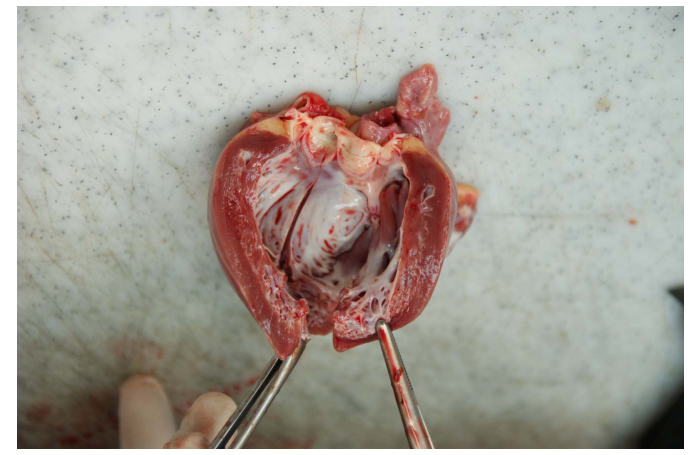

Figure 2 Left ventricular dilation with endocardial fibrosis and the inconspicuous aortic valve.

Diagnosis is usually established by the spongiform appearance on two-dimensional echocardiography and cardiac MRI. Multiple ventricular trabeculations, the presence of deep intertrabecular recesses and blood flow through the ventricular cavity and deep recesses are diagnostic. The Chin et $a l^{2}$ criteria focus on the depth of the recesses compared with the height of the trabecula, and the Jenni $e a^{3}$ criteria underline the importance of the presence of a two-layered structure.

Main symptoms are ventricular systolic dysfunction, heart failure, life-threatening arrhythmias and thromboembolic events, but the clinical spectrum ranges from asymptomatic patients to sudden cardiac death. ${ }^{24}$

Differential diagnosis includes hypertrophic or dilated cardiomyopathy, arrhythmogenic rightventricular cardiomyopathy and endocardial fibroelastosis.

The therapy consists of avoiding strenuous activities, treating chronic heart failure and administering antiarrhythmic drugs. Heart transplantation is the treatment of choice for patients with end-stage heart failure.

\section{Learning points}

- Left ventricular non-compaction is a rare congenital cardiomyopathy characterised by deep intertrabecular recesses in the left ventricular wall.

- Diagnosis is carried out by echochardiographic examination and MRI.

- Patients can be asymptomatic, suffering from arrhythmias or symptoms of severe heart failure. Cardiac transplantation remains the final therapeutic option for the treatment of irreversible end-stage heart failure.

Contributors CMS examined the explanted heart and wrote the article.

Competing interests None.

Patient consent Obtained. 
Provenance and peer review Not commissioned; externally peer reviewed.

\section{REFERENCES}

1 Engberding R, Bender F. Identification of a rare congenital anomaly of the myocardium by two-dimensional echocardiography: persistence of isolated myocardial sinusoids. Am J Cardiol 1984;53:1733-4.
2 Chin TK, Perloff JK, Williams RG, et al. Isolated noncompaction of left ventricular myocardium. A study of eight cases. Circulation 1990; 82:507-13.

3 Jenni R, Oechslin EN, van der Loo B. Isolated ventricular non-compaction of the myocardium in adults. Heart 2007;93:11-15.

4 Ritter $M$, Oechslin $E$, Sutsch $G$, et al. Isolated noncompaction of the myocardium in adults. Mayo Clin Proc 1997:72:26-31.

Copyright 2014 BMJ Publishing Group. All rights reserved. For permission to reuse any of this content visit http://group.bmj.com/group/rights-licensing/permissions.

BMJ Case Report Fellows may re-use this article for personal use and teaching without any further permission.

Become a Fellow of BMJ Case Reports today and you can:

- Submit as many cases as you like

- Enjoy fast sympathetic peer review and rapid publication of accepted articles

- Access all the published articles

- Re-use any of the published material for personal use and teaching without further permission

For information on Institutional Fellowships contact consortiasales@bmjgroup.com

Visit casereports.bmj.com for more articles like this and to become a Fellow 